\title{
STRATEGI MANAJEMEN RISIKO PEMBIAYAAN MURABAHAH STUDI KASUS DI BTN SYARIAH YOGYAKARTA
}

\author{
Dr. Sumar'in Asmawi dan Juliansyah, S.E, M.E
}

\begin{abstract}
Awareness of the risks are well understood is an integral part of efforts to optimize the benefits of a business, especially in the business in the financial sector. The purpose of this study was to determine the risk management and strategies to deal with it in a murabaha financing in BTN Syariah Yogyakarta. Qualitative approach used in this study. While the data obtained through interviews, observation, and documentation. The results showed that the management of risk in murabahah financing in BTN Syariah Yogyakarta must be doing by minimize the risk that happening, either ona precontractand postcontract. Mitigation pre-contract is done in compliance with Standard Operating Procedureset of internal bank, do selecting to mudharib's candidate, and feasibility analysis mudharib's candidate. While mitigating the risk of post-contract is used a standard system with computer technology with sigma program.
\end{abstract}

Keywords: Risk Management and Murabahab finance

\section{A. Pendahuluan}

Perbankan Syariah sebagai sebuah lembaga keuangan pada dasarnya melakukan tiga kegiatan pokok meliputi mrnghimpuh dana, pemberian pembiayaan dan memberikan pelayanan jasa keuangan lainya. Dalam aktivitasnya, institusi ini tidak lepas dari adanya risiko, sebagai konsekwensi dari proses bisnis yang di lakukan. Artinya tidak semua perencanaan mampu dijalankan sesuai harapan.

Risiko dalam konteks perbankan merupakan suatu kejadian potensial, baik yang dapat diperkirakan maupun yang tidak dapat diperkirakan yang berdampak negatif terhadap pendapatan dan permodalan bank. Risiko-risiko tersebut tidak dapat di hindari, tetapi dapat dikelola dan dikendalikan. Oleh karena itu, sebagaimana lembaga perbankan pada umumnya, bank syariah juga memerlukan serangkaian prosedur dan metodologi yang dapat di gunakan untuk mengidentifikasi, mengukur, memantau, dan mengendalikan risiko yang timbul dari kegiatan usaha yang disebut sebagai manajemen risiko. ${ }^{1}$

${ }^{1}$ Adiwarman A. Karim, Bank Islam Analisis Figh Dan Kenangan, (Jakarta;Raja Grafindo Persada, Edisike-3 2007) hal.225. 
Proses operasional yang di jalankan perbankan syariah pada prinsipnya adalah semua mekanisme yang menghindari sistem bunga, dan mengedepankan prisip Profit and Loss Sharing. Dalamaplikasinyaprinsip Profit and Loss Sharing(PLS) diaplikasikan dalam bentuk produk Mudharabah dan Musyarakah. Namun sering perkembanan lembaga keuangan syariah, produk ini dianggap terlalu berisiko tinggi dan sulit untuk diaplikasikan. Hal ini mendorong para cendekiawan dan praktisi perbankan syariah melakukan ijtihad untuk membuat produk baru, yang kemudian memunculkan salah satunya skim Murabahah.

Murabahah merupakan produk pembiayaan yang menyatakan harga perolehan dan margin keuntungan yang di sepakati oleh dua belah pihak.2 Skim ini merupakan produk pembiayaan yang lebih cenderung digunakan untuk jenis pembiayaan konsumtif dangan waktu yang relatif pendek.

Skim murabahan sebagai produk barun tidak sedikit menimbulkan pro dan kontra .mereka yang setuju terhadap konsep ini berpendapat bahwa konsep mark up dalam murabahah bukanlah timbul karena tempo pinjaman, melainkan timbul akibat adanya biaya-biaya dalam proses pelayanan ${ }^{3}$. Adapun ulama yang kontra terhadap skim ini menganggap produk Murabahah merupakan skim yang sama dengan bunga atau lebih mahal dari bunga,dan hal ini merupakan bentuk ekploitasi ${ }^{4}$.

Terlepas dari pro dan kontra terhadap murabahah, skim ini merupakan model pembiayaan yang sangat populer dalam dunia perbankan Indonesia. Hal ini dikarenakan produk ini dianggap sebagaiproduk yang mudah untuk diaplikasikan dan mempunyai risiko yang relatif kecil. Namun bagaimanapun, produk murabah ternyata tidak sepenuhnya bebas risiko, risiko pembiayaan tidak sepenuhnya dipengaruhi oleh jenis produk tapi juga sangat tergantung dari nominal, waktu pembiayaan dan variabel lain. Salah satu produk Murabahah yang dianggap memiliki risiko yang relatif tinggi adalah Kebutuhan Pemilikan Rumah (selanjutnya di sebut KPR Syariah).

Hadirnya produk KPR Syariah merupakan sebuah solusi dalam memberikan pembiayaan yang adil pada masyarakat. Berkaca pada produk KPR konvensensional, fluktuasi tingkat suku bunga yang cenderung mengalalami peningkatan dari waktu ke

\footnotetext{
${ }^{2}$ Ardiwarman A.Karim,Bank Islam Analisis Fiqhdan Keuangan, hal.115.

${ }^{3}$ Marvyn K. Lewis Dan Latifa M. Abgaoud, Perbankan Syariah, Prinsip, Praktik dan Prospek, Terj. Burhan Subrata, (Jakarta:Serambi Ilmu Semesta, 2007), hal 75.

${ }^{4}$ Ibid, Adiwarman Karim, hal. 118
} 
waktu menjadikan besaran pembayaran juga mengalami peningkatan. Dengan KPR Syariah hal tersebut dapat di hindari, dimana harga dan besarnya angsuran sudah ditetapkan diawal perjanjian.

Kebutuhan Pemilikan Rumah (KPR Syariah)adalah pembiayaan jangka panjang yang di berikan oleh bank baik bekerjasama dengan pengembang (developer) maupun yang dilakukan secara independen, untuk memberikan kemudahan bagi nasabah agar memiliki rumah sendiri dengan pembayaran sistem angsuran kepada bank dan menggunakan akadMurabahah.Dalamaplikasinya, produk ini merupakan produk pembiayaan yang memiliki risiko relatif besar. Berdasarkan hasil wawancara dengan pihak manajemen BTN Syariah,risiko finasial yang meliputi risiko kredit akibat kegagalan pembayaran pada saat waktu jatuhtempo, risiko pasar yang timbul akibat pergeseran harga, risiko operasioanal dan risiko hukum adalah beberapa risiko besar yang harus mampu dikelola oleh pihak perbankan dalam pembiayaan KPR Syariah.

Risiko pasar dalam pembiayaan KPR ini berkaitan dengan pergeseran harga dan tingkat suku bunga.Dalam konteks ini, biasanya perbankan syariah menggunakan suku bungga patokan (benchmark rate) untuk menilai (menentukan harga) beberapa instrumen keungan. Terutama dalam kontrak pembiayaan murabahah. Mark-up ditentukan dengan menambah risiko primium pada suku bunga patokan. Karena hal inilah, jika suku bunga yang menjadi patokan berubah, mark-up dalam kontrak berpendapatan tetap yang sudah diberjalan tidak dapat disesuaikan ulang. Sebagai akibatnya, perbankan syariah menghadapi risiko karena pergerakan tingakat suku bunga di pasar. ${ }^{5}$

Besarnya risiko keuangan yang timbul dari produk pembiayaan KPR ternyata tidak justru membuat pihak perbankan mempersulit atau menghindari pemberian pembiayaan dengan model ini. Masih di temukan perbankan nasional yang menjadikan produk pembiayaan KPR ini sebagai salah satu produk andalan, dimana salah satu perbankan yang di maksud adalah Bank Tabungan Negara (BTN) Syariah.

BTN Syariah merupakan salah satu unit usaha syariah dari Bank Tabungan Negara. Bank Tabungan Negara (BTN) adalah lembaga keungan perbankan yang

${ }^{5}$ Tariqullah Khan and Habib Ahmed,Manajemen Risiko Lembaga Kenangan Syariah, Terj.Ikhwan Abidin Basri (Jakarta: Bumi Aksara,2008), hal. .56 
mempunyai peranan yang sangat besar dalam percepatan pembangunan perumahan. BTN telah berkiprah di bidang jasa KPR sejak tahun 1953 dan pada tahun 1974 melalui penetapatan pemerintah, BTN ditunjuk sebagai bank milik pemerintah dengan penekanan usaha pada sektor tabungan dan lembaga pembiayaan perumahan. Pada tahun 2002 BTN berubah bentuk menjadi Persero dan ditunjuk sebagai bank umun dengan fokus pembiayaan perumahan tanpa subsidi.

Awal tahun 2005, BTN memulai pangsa pasar syariah dengan membuka unit usaha syariah bernama BTN syariah dibeberapa kota dansalah satunya adalah di Yogyakarta. KPR yang selama ini menjadi brand image PT BTN (persero) tetap dijadikan bisnis andalan BTN Syariah, dengan menerapkan prinsip pembiayaan rumah sesuai syariah, dengan akad Murabahan.

BTN Syariah sebagai salah satu perbankan syariah yang mempunyai core bisniss properti (perumahan) di pandang menarik karena selain berani mengambil risiko dalam bisnis ini, pangsa pasar bisnis properti yang di jalankan BTN Syariah juga pada pangsa pasar menengah kebawah ${ }^{6}$, artinya BTN lebih fokus pada bisnis ritel yang lebih menyentuh masyarakat bawah. Sementara dilain pihak perbank lain hanya berani untuk mendekati pasar koperasi. Hal ini membuktikan komintmen BTN Syariah sebagai lembaga perbankan yang sangat penduli pada masyarakat luas.

Praktik pembiayaan KPR Syariah di BTN Syariah pada prinsipnya dapat diterapkan dalam dua bentuk akad pembiayaan yakni pembiayaan murabahah dan pembiayaan Istisna.' Peneliti memfokuskan penelitian ini pada praktik pembiayaan KPR Syariah dengat akad murabahah, hal ini dengan alasan bahwa sampai saat ini praktik pembiayaan KPR yang dijalankan BTN Syariah di dominasi pada akad murabahah. Berdasarkan hasil wawancara peneliti dengan financing Service BTN Syariah, persentase pembiayaan KPR dengan akad murabahah mencapai 98\% lebih dan sisanya dilakukan dalam aplikasi KPR Syariah dilaksanakan dengan akad Istisna.'

Berdasarkan pemaparan diatas maka penulis merumuskan permasalahan dalam penelitian ini adalah "Bagaimnana Srategi Manajemen Risiko Pembiayaan Murabahah yang dilakukan BTN Syariah Yogyakartadalam produk KPR Syariah"?

${ }^{6}$ Muhammad Syafi'i Antonia, Bank Syariab:Dari Teori dan Praktek,Cet. 1(Jakarta:Gema Insan Press,2001) hal 25 


\section{B. Telaah Pustaka}

Skim murabahah dalam aplikasi perbankan ternyata tidak sepenuhnya digunakan dalam bentuk pembiayaan konsumtif jangka pendek, namun juga digunakan dalam aplikasi yang lain. Produk kpr syariah yang dilakukan oleh btn syariah merupakan salah satu bukti dimana produk murabahah juga digunakan untuk pembiayaan jangka panjang yang bersifat konsumtif.hal ini menjadikan risiko yang ditanggung dalam produk ini menjadi lebih kompleks dan memerlukan manajemen yang handal dalam menanganinya.

Penulis dalam penelitian ini mencoba untuk melakukan penelitian secara mendalam tentang strategi manajemen risiko khususnya dengan mengambil kasus pada btn syariah yogyakarta pada produk KPR syariah yang menggunakan akad murabahah. Berdasarkan kajian pustaka dan temuan literatur yang dilakukan penulis, dalam penelitian sebelumnya penulis belum pernah menemukan penelitian yang sama dengan penelitian yang akan penulis angkat.

Dari hasil penelusuran yang akan dilakukan penulis, ada beberapa tulisan ilmiah dan tesis yang bisa dijadikan pembanding sekaligus referensi yang sangat penting untuk mendukung penelitian ini. Buku karya abdullah saeed yang membahas sistem alternatif perbankan syariah yang menggunakan sistem bebas bunga (interes free banking); termasuk kajian fiqh dan historis sistem mudharabah, musyarakah dan murabahah yang dipraktikkan dalam pembiayaan perbankan syariah. ${ }^{7}$ dalam tulisan tersebut, abdullah saeed secara tegas melakukan kritik terhadap konsep dan prodak perbankan syariah.lewis dan algoud juga menulis tentang perbankan syariah dalam sudut pandang prinsip, praktik dan prospek.

Kajian tentang praktek pembiayaan di perbankan syariah diperoleh dalam buku manajemen pembiayaan bank syariaboleh Muhammad yang membahas tentang ruang lingkup pembiayaan syariah yang dilakukan perbankan syariah dalam menyalurkan pinjamannya. Isi buku ini yang mendukung penelitian adalah teknis pembiayaan di perbankan syariah dasar analisis arus kas (cash flow) pada pembiayaan syariah dan analisa kelayakan pembiayaan yang dilakukan oleh bank syariah.namun dari semua buku yang ditemukan ini belum membahas terperinci tentang pengaruh

${ }^{28}$ Abdullah Saeed, Bank Islam dan Bunga, Studi Kritis Larangan Riba dan Interpretasi kontemporer. Penerjemah: M. Ufuqul Mubin. (Pustaka Pelajar: Jakarta, 2004) 
strategi manajemen risiko pembiayaan murabahabyang karakteristik pembiayaannya dalam tempo waktu jangka panjang.

Tesis yang disusun oleh Iskandar (2009) yang berjudul manajemen risiko pembiayaan musyarakahpada bank pembangunan daerah (BPD) aceh syariah cabang Lhokseumawe periode 2007-2008 menjelaskan dengan mendetail strategi menajemen risiko pembiayaan musyarakabyang diterapkan BPD Aceh syariah meliputi sebuah kegiatan yang sangat komperhensifndaan sebagai bentuk penerapan prinsip prudent dalam menjalankan bisnis perbankan. Dalam temuannya Iskandar mengungkapkan bahwa setidaknya terdapat 5 (lima) risiko yang harus dikelola oleh pihak bpd aceh syariah dalam pembiayaan musyarakah yakni risiko pembiayaan, risiko kepatuhan, risiko legalitas, risiko operasional dan risiko pasar. Kelima risiko tersebut merupakan risiko potensial yang harus mampu dikelola oleh pihak manajemen dalam memberikan pembiayaan dengan akad musyarakah.

Tesis yang ditulis oleh Wasilul Chair (2008) dengan judul manajemen resiko pada pembiayaan mudharabah di bank syariah yogyakarta (studi atas bank muamalat indonesia, bank tabungan negara syariah dan bank syariah populer) menunjukkan bahwa bank syariah di yogyakarta memiliki sistem manajemen dalam memperkecil risiko pada pembiayaan mudharabah yaitu awal/sebelum akad pembiayaan, dalam perjalanan akad hingga setelah akad/setelah dana direalisasikan. Pada awal/sebelum akad bank syariah yogyakarta memastikan kelengkapan dan administrasi, dalam perjalanan akad bank syariah menganalisis dengan prinsip 5c, sedangkan sesudah akad bank syariah mengukur, mengawasi/monitoring dan mengendalikan resiko.

Penelitian yang terkait dengan murabahab penulis temukan pada tulisan anita rahmawaty dalam tesisnya yang berjudul kontroversi status keabsahan murabahah dalam perbankan syariah, telaah atas penerapan produk di bank muamalat semarang ${ }^{8}$. Dari hasil penelitian tersebut ditemukan bahwa kurang dari 90\% pembiayaan yang dijalankan pada tahun 1997 hingga tahun 1998 adalah didominasi praktik pembiayaan murabahah, dimana praktik

${ }^{29}$ Qi Mangku Bahtullah dalam Anita Rahmawaty,Kontoversi Status Keabsahan Murabahah dalam Perbankan Syariah, Telaah atas penerapan Produk di Bank Muamalat Semarang (Perpustakaan UIN Yogyakarta 2006). 
murabahah ini mendapatkan kritik dan dianggap tidak halal dan masih harus ditinjau kembali keabasahannya.

Penelitian yang dilakukan oleh Qi Mangku Bahjatulloh dalam tesisnya yang berjudul pembiayaan murabahah dalam wacana fiqh dan perbankan syariah (2007) menunjukan bahwa penetapan harga jualpembiayaan murabahah yang dinilai lebih tinggi dibanding dengan harga jual konvensional yang berbasis bunga karena dalam praktiknya, pengambilan margin yang lebih tinggi dianggap mampu mengantisipasi naiknya suku bunga dan inflasi.

Tesis yang ditulis oleh Syaparuddin (2007) yang berjudul kritik-kritik Abdullah Saeed terhadap praktik pembiayaan murabahah menemukan bahwa Abdullah Saeed dengan tegas menggugat praktik pembiayaan murabahah karena dianggap adanya kesenjangan antara teori dan praktik dan dianggap sebagai bentuk bunga terselubung. Adapun hal-hal lain yang dikritik dari praktik murabahah adalah 1) harga jual murabahab itu lebih tinggi 2) adanya nilai waktu luang dalam murabahah 3)tidak adanya batas keuntungan maksimal dalam murabahah 4) kontrak jual beli dalam murabahah hanya formalistic belaka.

\section{Metode Penelitian}

Penulis dalam melakukan penelitian ini menggunakan jenis penelitian lapangan (field research) yaitu suatu penelitian yang dilaksanakan secara intensif, terperinci dan mendalam dengan cara kualitatif. Penelitian kualitatif atau penelitian naturalistic adalah penelitian yang bersifat atau memiliki karakteristik, dinyatakan dalam keadaan sewajarnya atau sebagaimana adanya (natural setting), dengan tidak merubahdalam bentuk simbol-simbol atau bilangan. Penelitian ini mengeksplorasikan bagaimana strategi manajemen risiko pada skim pembiayaan Murababah yang dilakukan oleh BTN Syariah Yogyakarta pada produk KPR Syariah?

Data yang digunakan dalam penelitian ini ada dua sumber, yakni data primer dan sekunder. Data yang bersifat primer dalam penelitian ini adalah data yang berasal dari hasil observasi, interview atau wawancara dan dokumentasi. Hasil dari ketiga data tersebut dijadikan sumber primer oleh peneliti karena jenis penelitian ini adalah penelitaian lapangan (field research). 
Sedangkan data yang bersifat sekunder adalah yang diambil dari tulisantulisan atau buku-buku yang secara tidak langsung berkaitan dengan tema atau teori yang diteliti. Terutama buku-buku yang berhubungan dengan manajemen risiko duniaperbankan dan buku yang terkait dengan skim Murabahah.

\section{Temuan Lapangan dan Pembahasan}

\section{Identifikasi Risiko}

Proses identifikasi dan penilaian risiko yang dilakukan manjemen BTN Syariah merupakan bagian yang tidak dapat dipisahkan dari sistem dan mekanisme pengkajian risiko. Karena bagaimana pun, ketika karyawan melakukan proses pengkajian risiko, maka secara tidak langsung pihak karyawan juga harus melakukan identifikasi dan penelitian terhadap risiko baik secara keseluruhan maupun dari setiap jenis resiko.

Pada bagian ini,akan dipaparkan potensi risiko yang di dominan dari tiap jenis resiko yang menjadi pertimbangan dari pihak manajemen BTN Syariah dalam proses pembiyaan KPR Syariah. Berdasarkan hasil wawancara dengan pihak karyawan BTN Syariah Yogyakarta Risiko yang paling diperhitungkan adalah terkait tentang risiko pembiayaan.

Risiko pembiyaan merupakan risiko yang timbul akibat ketidakmampuan nasabah untuk mambayar kembali pokok dan margin yang telah ditetapkan dalam proses jual beli merubahah. Dalam pembiyaan ini,jumlah pokok margin telah ditentukan di awal abad angsuran dan pendapatan yang di peroleh bank akan bersifat tetap. Setidaknya ada tiga hal yang menyebabkan timbulnya resiko pembiayaan meliputi kegagalan pembayaran, hiden Information, moral Hazard.

Menurut indra salah satu pegawai bagian pembiayaan di BTN Syariah Yogyakarta menjelaskan, risiko pembiayaan di anggap sebagai risiko yang paling potensial bila di bandin dengan risiko lainnya. Hal ini disebabkan karena jangka waktu yang di berikan kepada nasabah dalam pembiayaan jenis ini yakni maksimal 15 ( lima belas) tahun dengan total angsuran 180 kali. Kegagalan pengelolaan risiko ini akan berdampak pada risiko lain seperti risiko likwiditas dan pendapat bank.

Lebih lanjut Menurut Indra tingkat komitmen nasabah untuk mengembalikan pembiyaan ini baru dapat diukur setelah pembiyaan berjalan diatas 
2(dua) tahun. Artinya dalam satu dua tahun awal, hampir tidak ada nasabah yang mengalami keterlambatan atau kegagalan bayar. Namun setelah tahun kedua, pihak bank baru dapat melihat kemampuan komitmen nasabah secara pasti. Pihak manajemen sendiri mengasumsikan tidak lebih dari 5\% untuk membiayai kemungkinan kegagalan bayar oleh nasabah dalam produk ini. Artinya sampai saat ini lebih dari 95\% nasabah mempunyai komitmen yang tinggi untuk membayar pembiayaan yang diberikan bank. Berdasarkan NPF (Non Performing Finance) sampai saat ini BTN Syariah masih dalam tahapan normal. Berdasarkan hasil wawancara dengan Fincing Servis (red:Indra) NPF BTN Syariah dalam tiga tahun terakhir ini rata-rata sebesar $4,3 \%$.

\section{Proses Manajemen Risiko Pembiayaan}

Manajemen risiko dimaknai sebagai seperangkkan prosedur yang harus dilalui dalam sebuah proses kerja,dalam hal ini mengenai prosedur pembiayaan KPR Syariah dengan akad murabahah.Seperti halnya di bank syariah lainnya,bahwa prosedur prosedur pembiayaan murabahah di BTN Syariah harus melalui beberapa tahapan.Hal ini sebagai upaya untuk mengurangi risiko yang mungkin terjadi dalam proses pembiayaan.

Menganalisis risiko pembiayaan merupakan salah satu tugas yang dibebankan pada Financing Service atau Accont Officer (AO). Berdasarkan hasil wawancara dengan Ata Nasrullah, Financing Service BTN Syariah Yogyakarta menjelaskan bahwa AO memegang peranan penting dalam mendukung keberhasilan dan pencapaian proses pembiayaan. Prinsip kehatian-hatian (prudent) dalam menyalurkan pembiayaan merupakan landasan utama yang harus di pegang oleh $\mathrm{AO}$ dalam melakukan analisis risiko. Hal ini sebagai upaya untuk menjaga kesehatan bank dan memperbaiki kinerja perusahaan.

Lebih lanjut Menurut Ata dalam upaya menjaga profesionalisme para Accont officer (AO) atau yang juga di istilahkan sebagai Financing Servicer,setiap AO di berikan kemampuan khusus dan spesifikasi untuk menganalisis jenis pembiayaan. Dari 3 (tiga) AO yang bertugas di BTN Syariah Cabang Yogyakarta,setiap orang di bekali dengan pembiayaan jual beli,Modal kerja dan sewa.

Pada dasarnya manajemen risiko pembiayaan murabahah di BTN Syariah khususnya produk KPR Syariah sudah terprogram. Artinya perusahaan sendiri sudah 
mempunyai SOP(Satuan Operasional Prosedur) sendiri sebagai tuntutan bagi para AP dalam menganalisis setiap risiko pembiayaan. Namun dalam aplikasi dilapangan,seringkali SOP masih bersifat fleksibel,menyesuaikan kondisi lapangan. Artinya,SOP tersebut bukanlah harga mati yang bersifat kaku. Setiap AO diberikan wewenang dan kepercayaan penuh untuk melakukan analisis dan penilaian risiko pembiayaan dengan catatan profesionalisme dan prinsip kehatian-hatian (prudent) harus dikedepankan dan melihat esensi dari pembiayaan itu sendiri.

Prosedur dan tahapan menganalisis risiko yang diterapkan di BTN Syariah Yogyakarta khususnya pada produk KPR Syariah ,merupakan bagian terpenting sebagai strategi manajemen risiko. Penting nya prosedur dan tahapan analisis risiko menjadi tolak ukur penentukan hasil dan pencapaian target pembiayaan.

a. Kebijakan dan Prosedur Pembiayaan KPR akad Murabahah

Produk pembiayaan kepemilikan rumah merupakan salah satu produk yang diperuntukkan bagi pemohon atau calon nasabah yang memenuhi persyaratan dengan tujuan pembiayaan komersil, berdasarkan prinsip murabahah untuk pembelian rumah dan atau berikut tanah. Berdasarkan hasil wawancara dengan Indra salah satu pegawai BTN Syariah menjelaskan bahwaProduk KPR yang dikelola BTN Syariah pada prinsip nya terdiri dari dua model produk,yakni produk pembiayaan KPR BTN iB dan Produk pembiayaan KPR Indensya BTN iB. Kedua jenis produk ini merupakan produk yang diperuntukkan dengan akad Murabahah.

Pembiayaan KPR BTN iB diperuntukkan bagi pemohon/calon nasabah yang memenuhi persyaratan dengan tujuan penggunaan untuk membeli rumah,rumah ruko,apartemen dan jenis rumah tinggal lainnya. Pembiayaan KPR BTN iB berdasarkan prinsip Murabahah,dimana harga jual didapatkan dari total harga beli dan margin (harga jual=margin).

Sedangkan pembiayaan KPR Indensnya BTN iB di peruntukkan bagi pemohon/calon nasabah yang memenuhi persyaratan dan dengan tujuam penggunaan untuk membeli tanah dan rumah dari Bank,yang di bangun oleh pengembang berdasarkan pesanan dari Nasabah,dimana pengembang telah bekerjasama dengan bank dalam hal penyediaan pembiayaaan KPR Indens nya BTN iB. 
Setidaknya terdapat beberapa keunggulan dan manfaat kedua produk ini. Adapun keunggulan yang di maksud meliputi :

a. Angsuran tetap sampai lunas

b. Maksimal pembiayaan KPR BTN Ib yang di dapat di berikan adalah $80 \%$ untuk nasabah non kolektif dan sebesar 90\% unyuk nasabah kolektif.

c. Jangka waktu pembiayaan maksimal sampai dengan 15(lim belas) tahun.

d. Lokasi rumah,rumah ruko,apartemen dan jenis rumah tinggal lainnya bebas di pilih oleh nasabah.

e. Margin bersaing

f. Persyaratan mudah dan fleksibel

g. Pelunasan di oercepat tidak dikenakan penalti

h. Berdasarkan prinsip syariah.

Pembiayaan KPR BTN syariah memberikan fasilitas pembiayaan murabahah dengan jangka waktu pembiayaan maksimal 15 (lima belas) tahun dengan masa angsuran perbulan selama 180 kali.Dalam produk ini pihak BTN Syariah mendapatkan imbalan berupa margin keuntungan dari selisih harga jual dan harga beli rumah dari developer atau perorangan. Perhitungan margin keuntungan tersebut menggunakan perhitungan sistem flat. Pembebanan margin keuntungan terhadap nilai pokok pinjaman yang bersifat tetap tanpa dipengeharui menurunnya jumlah nilai pokok pinjaman tersebut.

Pemohon dapat mengajukan rumah yang di pilih sendiri untuk dibiayai baik berupa rumah milik developer maupun rumah lama (rumah secound) milik perorangan. Rumah yang di biayai tersebut harus memiliki sertifikat baik berupa hak guna,hak milik,maupun hak milik tas suatu rumah susun dengan luas tanah minimal $60 \mathrm{~m} 2$ dan luas bagunannya memenuhi aspek teknis bangunan. Pada saat akad pembiayaan,rumah yang dibiayai harus dalam kondisi layak huni serta dilengkapi fasilitas berupa aliran air dan listrik yang telah berfungsi dengan baik.

Rumah tersebut terletak di daerah pemukiman sesuai RUTRK (Rencana Umum Tata Ruan Kota) yang sudah di lengkapi dengan saran prasarana lingkungan serta bebas bahaya banjir. Khusus untuk rumah tinggal yang berada di luar kawasan perumahan,berlaku ketentuan jalan lingkungan depan rumah minimal dapat dilalui kendaraan roda empat. Dalam pembiayaan KPR BTN Syariah,rumah yang di beli 
nasabah menjaadi agunan untuk bank sehingga letaknya harus memenuhi penilaian berupa kemudahan untuk di jual kembali dan mudah di jangkau.

Pada saat pemohon mengajukan permohonan pembiayaan,setelah mengisi aplikasi permohonan serta dokumen kelengkapan biaya, pemohon harus menyediakan uang muka yng besarnya di tetapkan oleh BTN Syariah dan di setujui oleh nasabah. Biasanya besarnya uang muka sebesar 10-20\% dari harga beli rumah yang akan dibiayai. Uang muka tersebut (urbun) harus di bayar terlebih dahulu oleh pemohon pada bank sebagai salah satu syarat yang harus di penuhi pemohon untuk memperoleh fasilitas pembiayaan yang murabahah dari BTN Syariah.

Apabila terjadi perubahan atau pembatalan pesanan dari pihak pemohon, maka pihak BTN syariah dapat pempergunakan urbun tersebut sebagai ganti rugi atas biaya yang telah di keluarkan pihak bank. Pembebanan urbun tersebut selain sebagai uang muka, urbun juga merupakan bukti keseriusan bagi calon pemohon untuk mengajukan pembiayaan.

Risiko merupakan masalah alamiah yang terjadi dalam setiap aktifitas bisnis. Setiap usaha yang mengharapkan keuntungan pasti dibebankan risiko.dalam menghadapi risiko setidaknya ada beberapa alternatif bisa dipilih oleh manajer.

Demikian pula halnya yang terjadi dalam bisnis perbankan, BTN syariah sebagai sebuah intitusi bisnis perbankan dalam memberikan pembiayaan khususnya dengan akad murabahah pada produk KPR syariah juga mempunyai risiko. Dalam menghadapi risiko, pihak manajemen BTN syariah setidaknya mengambil 3 (tiga) langkah. Adapun ketiga langkah yang dimaksud meliputi: 
a. Pengendalian atau pengelolaan risiko (Risk Control)

Pengendalian risiko dilakukan dengan menerima risiko pada tingkat tertentu dengan melakukan tindakan untuk mengurangi dan mengendalikan risiko melalui peningkatan kontrol, kualitas proses serta aturan yang jelas terhadap pelaksanaan aktifitas dan risikonya.

b. Pengalihan risiko (Risk Transfer)

Pengalihan hal ini dilakukan dengan mengalihkan risiko pada pihak lain. Kosekwensinya terdapat biaya yang harus dikeluarkan atau berbagi profit dengan pihak lain.

c. Menghindari risiko (Risk, Avoidance)

Keputusan untuk tidak melakukan suatu aktivitas bisnis merupakan cara yang paling mudah, namun hal ini merupakan keputusan yang tidak strategis dalam usaha mengharapkan keuntungan. Keputusan untuk menghindari risiko tentunya juga merupakan pilihan untuk tidak mengambil profit dalam bisnis.

Ketiga pilihan yang di ambil pihak manajemen dalam menghadapi risiko tersebut, amplikasinya diterapkan bedasarkan beberapa pertimbangan diantaranya besar kecilnya risiko, tipe risiko dan kemampuan pihak manajemen untuk mengelola risiko tersebut. Selanjutnya praktik dan amplikasi dalam menghadapi risiko akan dibahas secara satu persatu.

b. Pengendalian atau Pengelolaan Risiko (Risk Control) Pembiayaan Murabahah

Pengendalian atau pengelolaan risiko merupakan salah satu alternatif yang dipilih pihak manajemen terhadap potensi risik yang timbul dari sebuah aktufitas bisnis. Pilihan ini merupakan bentuk kecekapan dan kemampuan pihak manajemen untuk mengelola risiko dalam upaya untuk menghasilkan keuntungan sesuai tujuan dari aktivitas bisnis yang dijalankan. Praktik pengendalian risiko ini tercermin dalam aplikasi prosedur manajmen risiko yang diterapkan oleh pihak manajemen dari setiap pembiayaan.

Proses menerapkan manajemen risiko yang diberlakukan di BTN syariah menurut peneliti merupakan sebuah proses yang salig terkait dan mempunyai ruang lingkup yang sangat komperhensif dan luas. Hal ini mengingatkan pentingnya manajemen risiko dalam meningkatkan pendapatan bank itu sendiri. 
Penerapan manajemen risiko yang diterapkan oleh pihak BTN syariah sesungguhnya tidak lepas dari 3 (tiga) hal penting meliputi sistem yang diterapkan (alat dan teknologi), user (pihak yang menerapkan) serta waktu (time) yang dijadikan patokan. Tiga hal ini merupakan satu kesatuan yang menjadi bukti profesionalisme sistem manajemen risiko dalam sebuah pembiayaan di BTN syarian Cabang Yogyakarta.

Pembiayaan murabahah KPR syariah merupakan jenis pembiayaan jangka panjang (long time) yang sangat rentan terhadap risiko pembiayaan. Kegagalan pembayaran ansuran oleh nasabah salah satu nya disebabkan oleh bentuk prilaku moral hazard. Prilaku ini disebabkan oleh kekaburan informasi (advanseselection) tentang nasabah.

Oleh itu, dalam upaya untuk menghindari timbulnya kekaburan informasi (advanse selection) dan kegagalanPembayaran angsuran, pihak manajemen BTN syariah menerapkan prosedur manajemen risiko pembiayaan yang terdiri dari seksi awal, analisis pembiayaan dan monitoring.

1) Seleksi awal

Tahapan seleksi merupakan tahapan awal dalam proses pembiayaan KPR syariah. Tahapan ini bertujuan untuk menghindari kekaburan informasi tentang nasabah dan usaha bisnis yang di jalankan calon nasabah. Dalam tahapan ini dilakukan analisis mendalam tentang identitas nasabah serta kondisi usah nasabah (bagi nasabah swasta damn profesional) dan legalitas bisnis nasabah. Tujuan utama dalam proses seleksi awal ini adalah untuk melihat keterangan mendalam tentang calon nasabah dan kondisi serta legalitas usaha.

Dalam rangka mencari informasi tersebut, terdapat beberapa metode yang digunakan oleh pihak bank meliputi:

a) Penelitian Berkas

Berdasarkan prosedur dan kebijakan pembiayaan, calon nasbah yang akan mengajukan pembiayaan diwajibkan untuk mengisi formulir pembiayaan dan menyertakan dokumen-dokumen lainya. Dokumen-dokumen tersebut, tentunya hal-hal yang terkait dengan data nasabah dan informasi usahaYang merupakan prasarat bagi setiap calon nasabah pembiayaan. 
b) Survei Lapangan

Untuk memastikan kondisi usaha yang dijalankan nasabah, pihak bak akan melakukan survei. Keterangan lapangan yang diperoleh jugaPenting digunakan untuk menilai kelayakan usaha nasabah. Dari kelayakan usaha, diperoleh kemampuan keuangan. Tindakan sirvei ke lapangan ini merupakan bentuk kehati-hatian (prudent) bank sebelum memberikan pembiayaan.

c) Wawancara

Wawancara dipandang sangat penting untuk mengungkap informasi dari nasabah berdasarkan subjektifitas nasabah itu sendiri. Kecendrungan nasabah dalam pembiayaan KPR syariah adalah nasabah yang belum pernah sebelumnya mengambil pembiayaan dalam produk ini, berbeda dengan produk lain, nasabah KPR syariah mayoritas membeli rumah untuk kebutuhan pribadi, sehingga ia hanya membeli rumah satu kali saja.

Proses wawancara juga merupakan waktu dimana, pihak manajemen bank melihat keseriusan nasabah untuk mengambil dan melunasi pembiayaan yang diberikan bank. Wawancara ini merupakan waktu paling efektif dalam memberikan penilaian terhadap carakter seseorang. Dari bahasa tubuh, mimik wajah dan cara berbucara pihak manajemen akan memberikan penilaian terhadap komitmen dan keseriusan calon nasabah.

d) Informasi dari BI

Stategi berikutnya yang harus dilakukan oleh pihak AO dalam mendalami informasi tentang nasabah adalah melihat informasi tentang data nasabah di pusatData BI. Seorang AO harus memastikan bahwa pemohon pembiayaan apakah pernah atau sedang mempunyai pinjaman di bank lain dan dapat dikategorikan lancar atau tidak.

2) Analisis dan Pengukuran Risiko Pembiayaan Murabahah

Salah satu aspek pentik untuk menghindari pembiayaan bermasalah dalam BTN syariah adalah dengan melakukan analisis dan pengukuran risiko yang dilakukan oleh AO (account officer) pada pembiayaan murabahah dalam produk KPR syariah adalah bebrapa metode. 
(a) Metode The 5 C's Credit Analysis

Menurut indra pemberian pembiayaan pada seorang nasabah agar pembiayaan dilakukan tepat sasaran dan sesuai tujuan bank, maka bank harus menerapkan sistem analisis pembiayaan. Analisis pembiayaan yang di lakukan oleh pihak BTN Syariah dalam menganalisis pembiayaan adalah dengan analisis 5C's penerapan metode ini harus dilakukan dengan tepat dan teliti sehingga analisis pembiayaan benar-benar dapat terukur dengan baik. Kelima hal tersebut meliputi:

\section{Charakter (penilaian watak)}

Merupakan analisis watak dan sifat dari nasabah. Analisis karakter ini sangat penting dilakukan oleh bank, karena hal ini berkaitan dengan sejauh mana itikad dan kemauan nasabah untuk memperoleh pembiayaan dan sekaligus untuk membayar pembiayaan sesuai kewajiban dan akad yang telah disepakati.

\section{Capasity (penilaian kemampuan)}

Penilaian kemampuan ini dilakukan untuk menilai sejauhmana kemampuan nasabah untuk mampu membayar dan melunas pembiayaan sesuai dengan akad yang di sepakati. Dalam penilaian kapasiti ini biasanya pihak AO menggunakan pendekatan finansial para nasabah.

3. Capital (penilaian terhadap modal)

Pengukuran penilaian capital didasarkan pada sejaumana kemampuan calon nasabah untuk mampu membayar urbun (uang muka) pembiayaan tersebut. Karena dalam pembiayaan KPR Syariah uang muka ditanggung oleh nasabah yakni sebesar $10-20 \%$ dari harga rumah.

Dalam pembiayaan KPR Syariah nasabah tidak hanya dibebankan membayar uang muka, tapi juga biaya-biaya lain yang menunjang proses pembiayaan seperti biaya administrasi, biaya premi asuransi jiwa dan kebakaran, dana mengendap, biaya appraisal tanah dan atau bangunan serta biaya-biaya lain, sesuai klausul akad.Selain dari kemampuan membayar uang urbun dan biaya lain, Capital juga dilihat dari catatan laporan keuanagan bisnis yang dijalankan calon nasabah, apakah perkembangannya semakin meningkat dari waktu ke waktu.

4. Collateral (penilaian terhadap angunan)

Pada hakitaknya bentuk angunan dalam pembiayaan KPR Syariah adalah rumah yang akan dijual itu sendiri. Oleh itu, dalam melakukan penilaian collarel ini, 
pihak AO akan melakukan survei lapangan untuk melihat kondisi dan situasi rumah, serta melakukan penilaian terhadap rumah tersebut berdasarkan kondisi bangunan. Akses dan kondisi pasar.

5. Conditional of economic ( penilaian terhadap ekonomi)

Dalam melakukan penilaian kondisi ekonomi, hal ini sangat dipengaruhi oleh faktor makro meliputi kondisi poloitik, sosial, keonomi dan budaya yang berakibat pada keadaan perekonomian yang mungkin suatu saat akan mempengaruhi kelancaran proses pembayaran pembiayaan oleh nasabah.

Kondisi-kondisi ekonomi yang dominan yang harus diamati secara mendalam meliputi kondisi pasar, teknis produksi secara makro serta masalah kebijakan pemerintah.

(b) Analisi pembiayaan kuantitatif

Analisis ini dilakukan dengan menggunakan metode financing scoring model yang terdiri dari 3 (tiga) pilar kelayakan pembiayaan, yaitu kemampuan membayar, kemauan membayar dan kehandalan angunan. Ketiga pariabel penilaian ini dilakukan dalam sebuah sistem komputer. Sehingga kelayakanPembiayaan dapat dimunculkan dalam data komputer berdasarkan risiko pembiayaan tersebut. Adapun penilaian risiko pembiayaan tersebut berdasarkan

\begin{tabular}{|l|l|}
\hline \multicolumn{1}{|c|}{ Model Skoring } & \multicolumn{1}{c|}{ Tingkat Risiko } \\
\hline $1=$ baik sekali & Very low risk \\
$2=$ baik & Low risk \\
$3=$ cukup/sedang & Mederat risk \\
$4=$ kurang & High risk \\
$5=$ buruk sekali & Very hig risk \\
\hline
\end{tabular}

Hasil analisis ketiga model tersebut selanjutnya dirata-ratakan untuk melihat apakah financing scoring model hasil analisisnya masih dalam batas toleran manajemen risiko atau tidak.

(c) Analisis pembiayaan kualitatif

Analisis ini dilakukan terhadap keseluruhan kondisi pemohon pembiayaan, lingkungan bisnis, dan faktor-faktor lain sebagai tambahan untuk hasil scoring serta alasan-alasan khusus pemberian pembiayaan. Alasan tersebut antara lain, berupa 
perkembangan kondisi usaha, penilaian secara rinci dan jelas terhadap kemampuan membayar, serta ketersediaan dokumen-dokumen pendukung.

3) Monitoring

Tindak lanjut dari proses pembiayaan adalah monitoring. Monitoring merupakan proses pengendalian risiko pembiayaan yang diterapkan pihak manajemen. Proses monitoring yang dilakukan pihak manajemen BTN Syariah dalam produk KPR ini yakni dengan melihat proses angsuran nasabah, apakah sudah sesuai waktu yang ditentukan atau terjadi keterlambatan.

Sistem pengawasan dilakukan dengan menggunakan sistem baku dengan teknologi komputer program sigma. Dengan program ini pihak manajemen bisa memantau angsuran nasabah tiap bulan. Sehingga ketika terjadi keterlambatan angsuran dengan cepat dapat diketahui dan diantisipasi.

Pelaksanaan pengawasan dibagi dalam dua tahap. Pada periode satu tahun pertama pengawasan dilakukan oleh pihak AO (Account officer). Hal ini sebagai bentuk tanggung jawab terhadap analisis pembiayaan yang dilakukan AO. Untuk peridoe berikutnya sampai akhir proses pelunasan, pengawasan dilakukan sepenuhnya oleh Financing recovery. Bagian ini selanjutnya bertanggung jawab penuh untuk melakukan monitoring dan tindak lanjutnya terhadap proses angsuran nasabah.

Dengan sistem dan manajemen pengelolaan risiko permbiayaan pada akat Murabahabtersebut. Penilaian terhadap efektivitas pengelolaan manajemen risiko dalam risiko pembiayaan murabahah ini secara umum cukup efektif. Hal ini terlihat dari tingkat NPF (Non Perfoming Finance) pembiayaan KPR Murabahah terus dapat di turunkan dari tahun ketahuannya. Berdasarkan hasil wawancara dengan indra, penurunan angka NPF untuk wilayah Cabang Yogyakarta dari tahun terus meningkat hal ini merupakan sebuah prestasi dari sistem pengelolaan manajemen risiko. Periode 2008-2009 setidaknya terjadi penurunan NPF sebesar 10\%, dan pada periode tahun 2009-2010 terus ditekan menjadi 15\%. Pada skala nasional dalam 3 tahun terakhir untuk pembiayaan KPR dengan akad Murabahah tingkat NPF ini juga terus menurun, dimana rata-rata NPF tersebut sebesar 4,3\%. Berdasarkan Neraca 
Per 30 Juli 2009 yang dikeluarkan oleh BTN Syariah Menunjukkan bahwa tingkat penyusutan piutang murabahah hanya sebesar 5,99\% dari total piutang murabahah.

Kemampuan pihak manajemen dalam mengelola risiko pembiayaan murabahah pada produk KPR Syraiah ini juga ditunjukkan dari tingginya komitmen nasabah untuk mengembalikan angsuran yang diberikan. Dimana dari tahun ketahun tingkat komitmen nasabah ini terus dapat dtingkatkan. Tingkat rata-rata komitmen nasabah untuk mengembalikan pembiayaan mencapai angka 95\% lebih. Artinya hanya kurang dari 5\% nasabah yang tidak loyal atau perlu tekanan untuk mengembalikan pembiayaan yang diberikan. Walau demikian angka ini terus berusaha untuk ditekan sekecil mungkin, sebagai upaya untuk memperkecil risiko pembiayaan ini.

Adapun tingkat pembiayaan KPR yang dilakukan oleh BTN Syariah dari tahun ketahun terus mengalami peningkatan. Artinya setiap tahun target pembiayaan yang disusun oleh pihak manajemen mampu untuk dicapai dan bahkan mampu untuk melibihi target portofolio pembiayaan KPR Syariah. Dimana sampai saat ini, KPR Syariah merupakan salah satu produk yang sangat diminati oleh masyarakat luas.

\section{Kendala dan Hambatan Manajemen Risiko}

Pelaksanaan manajemen risiko merupakan sebuah prose durpenting yang harus diterapkan untuk memperkecil risiko yang mungkin terja di.Dalam aplikasinya, proses ini merupakan sebuah kesatuan dari rangkaian mekanis memanajemen risiko yang terdiri dari sistem, user dan waktu.

Ketiga hal ini diharapkan untuk selalu berjalan seirama dan sesuai ketentuan prose dur yang telah ditetapkan pihak manajemen. Dalam kenyataannya,kegiatan manajemen risiko tidak luput dari kendala dan hambatan. Dimana hambatan tersebut sangat terkait dengan tigam ekanis memanajemen risiko itu sendiri.

1. Sistem

Sistem yang dimaksud dalam variabel maanjemen resiko ini adalah prosedur operasi onal dantools (teknologi) yang digunakan dalam menunjang proses manajemen 
risiko. Sistem ini, merupakan serangkaian prosedur yang harus dilalui oleh karyawan dengan alat dan teknologi yang telah ditetapkan.

Sebagai sebuah lembaga perbankan syariah, BTN Syariah merupakan institusike uangan yang masih terbilang baru.Hal ini menjadikan sistem yang diterapkan sering kali kurang tepat dan tidaka plikatif. Perbedaan persep siantara sistem dan kondisi lapangan menuntut pega waiharus melakukan penyesuaian.

Selain itu, masalah keterbatasan teknologi juga merupakan salah satu kendala yang harus diselesaikan. Hal ini mengingatusia BTN Syariah yang masih sangatbaru, sehingga sebagian teknologi dan sistem yang digunakan merupakana dopsidarisis temper bankan konvensional, yakni BTN induk. Penggunaan sistem konvensional bisa dibenarkan dengan catatan tidak melanggar prinsip syariah. Karena bagaiman pun apsek syariah harus tetap dijaga dan dipertahankan sebagai sebuah identitas perbankan.

\section{User}

Aktivitas apapun, user (manusia) merupakan bagian yang tidak terpisahkan sebagai pelaku untuk menjalankan sebuah sistem.Sesempurna dan secanggih apa punsistem yang digun akan tidak ada artinya tanpa didukung user yang faham dan mengert \i untuk menjalan kansisem tersebut. Demikian pula halny adalam proses penerapan manajemen risiko, pada hakikatnya sistem dan prosedur yang telah ditetapkan oleh pihak manajemen, harus mampu untuk diterapkan oleh pegawai.

BTN Syariah merupakan sebuah perbankan yang menerapkan prinsip syariah yang masih terbilang baru.Untuk skala nasional, keterlibatan BTN Syariah dalam duni aperbankan syariah baru berusia 5 (lima) tahun. Keterbatasan pengalaman sangat berpengaruh terhadap kinerja pegawai dalam menjalankan sistem yang telah ditetap kan pihak manajemen.

Selain itu, berdasarkan hasil observasi peneliti dilapangan menunjukkan sebagian besar pegawai terutama bagian analisis pembiayaan merupakan fressgraduet (sarjana) yang belum banyak berpengalaman di bidang perbankan dan keuangan syariah.Walau demikian pihak BTN Syariah terus berupaya untuk meningkatkan profesiona lisme para karyawan. Hal ini, disatu sisi sebagai sebuah ke untungan dimana tenaga yang digunakan adalah tenaga baru yang energik dan kreatif, namun disisi lain. 
Salah satu aspek profesional ismesangat ditentukan dari masalah pengalaman.Catatan lain sebagai kendala pada variabel ini adalah keterbatasan jumlah pegawai. Berdasarkan observasi lapangan menunjukkan bahwa jumlah pegawai pada bagian ini hanya berjumlah 3 (tiga) orang. Tiga orang yang dimaksud adalah bagian AO (accont officer) yang bertugas untuk melakukan analisis pembiayaan dan pengukuran risiko. Pegawai sering kali kesulitan untuk mengerjakan pekerjaan yang begitu banyak. Selain itu tugas AO sesuai kebijakan manajemen selain bertugas untuk menganalisis pembiayaan, juga dibebankan untuk melaku kan pemasaran dilapangan. Kondisi tugas ganda tersebut selain sebagai sebuah keunggulan dimana AO sangat faham dengan calon nasabah, juga merupakan sebuah kelemahan. Hal ini menjadikan $\mathrm{AO}$ harus terpecah konsentrasinyase lain tuntutan untuk melakukanana lisissecarapro fesional juga harus mengejar target tahunan yang telah ditentukan perusahaan.

3. Waktu

Dalam penerapan mana jemen risiko variabel waktu merupakan variabel yang sangat diperhitungkan untuk mengukur profesiona lisme dalam upaya memberikan pelayanan terbaik pada nasabah.Pihak manajemen BTN Syariah telah menetapkan 7 (tujuh) hari merupakan rentang yang harus dipenuhi dalam proses penanganan pembiayaan mulai dari proses pengajuan permohonan, penandatangan anak adsampai proses pencairan. Penetapan 7 (tujuh) hari sebagai waktu proses pembiayaan diterapkan dalam semua proses pembiayaan akad Mubarabah dengan nominal yang tidak terbatas.

Penetapan waktu proses pembiayaan, memungkinkan timbulnya human error (kesalahan karyawan) dalam melakukan analisis pembiayaan dan proses-proses lain dalam pembiayaan. Terjadinya human error merupakan salah satu pengaruh singkatnya rentang waktu proses analisis. Jumlah Accont officer sebanyak 3 (tiga) orang dalam waktu dan kondisi tertentu, seringkali tidak seimbang dengan banyaknya permohonan pembiayaan yang harus dianalisis. Kondisi ini selain memungkinkant erjadinya buman error juga menimbulkan penilaian dan analisis subjektif dari accont officer. Penilaian yang subjektif tentunya sangat berpengaruh pada besarnya risiko pembiayaan yang menimbulkan tingginya moral hazard dan kegagalan pembayaran dari nasabah. 


\section{E. Kesimpulan}

Manajemen risiko dalam pembiayaan mudharabah di Bank Tabungan Negara (BTN) Syariah Yogyakarta adalah suatu upaya untuk meminimalisir risiko yang terjadi, baik pada tahapan pra akad dan pasca akad. Manajemen risiko dilakukan oleh pihak manajemen meliputi pra akad dilakukan dengan mematuhi Standard Operational Procedure yang ditetapkan internal bank, melakukan seleksi calon nasabah, dan melakukan analisa terhadap kondisi dan keuangan nasabah. Sedangkan mitigasi risiko pasca akad dilakukan dengan monitoring dengan menggunakan sistem baku dengan teknologi komputer program sigma.Adapun kendala yang dihadapi oleh pihak manajemen dalam pengelolaan manajemen risiko meliputi masalah user, masalah sistem dan masalah waktu.

\section{DAFTAR PUSTAKA}

Abdullah Saeed, Bank Islam dan Bunga, Studi Kritis Larangan Riba dan Interpretasi kontemporer. Penerjemah: M. Ufuqul Mubin. (Pustaka Pelajar: Jakarta, 2004)

Adiwarman A. Karim, Bank Islam Analisis Figh Dan Kenangan, (Jakarta;Raja Grafindo Persada, Edisike-3 2007)

Ferry N. Idroes, Manajemen Risiko Perbankan: Pemahaman Pendekatan 3 Pilar Kesepakatan Basal II TerkaitAplikasi Regulasi dan Pelaksanaannya di Indonesia (Jakarta : Rajagrafindo Persada, 2008)

Hermawan Darmawi, Manajemen Risiko. Cet-9 (Jakarta: Bumi Aksara, 2005)

Mamduh M. Hanafi, Manajemen Risiko (Yogyakarta: UPP STIM YKPN, 2006)

Marvyn K. Lewis Dan Latifa M. Abgaoud, Perbankan Syariah, Prinsip, Praktik dan Prospek, Terj. Burhan Subrata, (Jakarta:Serambi Ilmu Semesta, 2007)

Muhammad Syafi'i Antonia, Bank Syariah: Dari Teori dan Praktek, Cet. 1 (Jakarta:Gema Insan Press,2001)

Muhammad, Manajemen Bank Syariah,edisi revesi (Yogyakarta: UPP STIM YKPN, 2005)

Muhammad Taqi Usmani, An Introduction to Islamic Finance (Pakistan: Idratul Ma'arif, 2001) 
Moh. Daud Bakar, Essensial Reading In Islamic Finance (Kuala Lumpur: CERT Publition, 2008)

Qi Mangku Bahtullah dalam Anita Rahmawaty, Kontoversi Status Keabsahan Murabahah dalam Perbankan Syariah, Telaah atas penerapan Produk di Bank. Muamalat Semarang (Perpustakaan UIN Yogyakarta 2006)

Rifqi Muhammad, Akuntansi kenangan syaria,(Yogyakarta:P3EI Press, 2008)

Tariqullah Khan and Habib Ahmed, Manajemen Risiko Lembaga Kenangan Syariah, Terj.Ikhwan Abidin Basri (Jakarta: Bumi Aksara,2008)

Zainul Arifin, Dasar-dasar Manajemen Bank Syariah (Jakarta: Alvabet, 2005) 